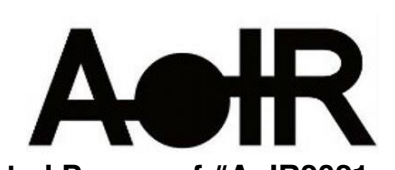

Selected Papers of \#AolR2021:

The 22nd Annual Conference of the

Association of Internet Researchers

Virtual Event / 13-16 Oct 2021

\title{
EMERGENT GOVERNANCE: COMPETITION POLICY AS PLATFORM REGULATION
}

\author{
Pawel Popiel \\ University of Pennsylvania
}

\section{Introduction}

Much of the scholarly debate around platform regulation and governance is outcomefocused, concerning rules and norms that should govern platform behavior, rather than focusing on questions of policy processes (Haggart, 2020). However, the question of politics underlying the development of these rules is essential to understanding how and why particular forms of oversight have developed in response to the growing scope of platformization (van Dijck, 2020) and broader political economic changes theorized as platform and surveillance capitalism (Srnicek, 2017; Zuboff, 2019). Indeed, despite multiple dimensions of the policy debate, most interventions in places ranging from the US to the EU to India to Australia have taken the form largely of competition policy (e.g., Evens et al., 2020; Puppis \& Winseck, 2020). To address this gap, this paper provides a preliminary account of how competition policy has emerged as a prominent governance mechanism for platform oversight, which privileges stronger antitrust enforcement and economic regulation and has resulted in antitrust lawsuits against and investigations into major tech companies like Google and Facebook.

\section{Design \& Methods}

With the US as a case study, I examine a series of $2017-2020$ policy debates about the oversight of digital platform markets, arising partly in response to public scandals like Cambridge Analytica and regulatory gaps resulting from technological convergence, digitization, and neoliberal reforms. Drawing on critical discourse analysis of policy documents (e.g., regulatory hearing transcripts and think tank reports on digital platforms), a dozen policy stakeholder interviews (e.g., competition policy experts, tech policy advocates, regulators), and fieldwork in Washington, D.C. (e.g., expert antitrust panels), I trace these debates across several prominent policy venues, including Stigler

Suggested Citation (APA): Popiel, P. (2021, October). Emergent Governance: Competition Policy as Platform Regulation. Paper (or panel) presented at AolR 2021: The 22nd Annual Conference of the Association of Internet Researchers. Virtual Event: AolR. Retrieved from http://spir.aoir.org. 
Conferences on digital platforms and the eponymous report; the 2018-2019 FTC hearings on competition in digital markets; and a series of antitrust events, panels, and symposia organized by many stakeholders active in the competition policy space. Drawing on critical policy studies (Fischer, 2003; Schmidt, 2015), I explore how the boundaries of competition policy are discursively contested and negotiated in these debates by stakeholders ranging from policy experts to regulators to public interest groups. I identify the range of interests invested in clashes over policy, including competing definitions of digital platform markets; proposed policy interventions and expectations about their outcomes; and the proper role of the state and of market competition in digital platform markets.

\section{Emergent Governance}

Driven by a burgeoning progressive antimonopoly movement, these 2017-2020 debates took place in the broader policy arena-regulatory hearings, nonprofit events, academic conferences, legal journal articles, newspaper op-eds-where a critique of existing antitrust began to take form. This critique principally revealed how existing neoliberal antitrust's definition of competition in terms of outcomes (e.g., price effects) entrenches the market power of massive tech incumbents. Anti-monopolists analyzed the competitive concerns arising in digital platform markets so painstakingly they simply could not be swept aside by the antitrust establishment. They also worked to normalize antitrust tools considered radical, like breakups, significantly expanding the discursive space in the competition policy arena. A new reform discourse had emerged: competition as a tool of democratic governance over private markets. The subsequent process of policy sense-making, in which policy communities attempt to work out complex and often uncertain policy problems (Andrews, 2020), involved intense political debate and critique of these proposals by the industry and by various stakeholders on policy and ideological grounds. As the less radical ideas were taken up by the antitrust establishment, many of the antimonopoly critiques became legitimated. Importantly, some of these proposals also resonated with right-wing populists allied with the Trump Administration, who saw antitrust as a tool for exerting political information controls, namely by applying pressure on digital platform giants falsely accused of censoring conservative speech.

However, competition is elusive in platform markets and the problems arising in them extend beyond competitive concerns. The idea of antitrust and regulation as complements to address platform power emerged as a product of two opposing forces reacting to the antimonopoly intervention. The political right strategically argued that antitrust was purposely too narrow to address non-competition-related concerns as an attempt to fend off any antitrust reform proposals. Establishment experts on the center and center-left agreed, particularly those steeped in decades of media policy who instinctively linked market failure with regulation, while leftists saw competition as fundamentally limited in achieving key policy goals, such as worker protections. While anti-monopolists worried that regulatory solutions would distract from their broader project of antitrust reform, even some expanded their definition of competition policy to accommodate regulation. Ultimately, the regulatory proposals taken up by the policy establishment were largely confined to economic regulation. 
These policy debates produced a set of policy ideas and values vis-à-vis platform oversight that coalesced around a governance paradigm constructed by an interpretive community (Hassan et al., 2020) of policy experts. Rooted in competition policy, the framework discarded some of the bolder proposals, like structural separation, in deference to market mechanisms and narrower economic regulations, like mandated interoperability. The Biden Administration in dialogue with regulators across the globe has embraced a more interventionist approach, but ultimately prioritizes optimizing competition in digital platform markets above other goals, like data regulation.

Consequently, it risks coming up short in providing a policy answer to the expansive forces driving platform capitalism. Indeed, competition policy inherently privileges solutions that focus on individual, usually big, companies. As a result, the policy debate remains tethered to the activities of platform giants, while platformization-a process that implicates an increasingly massive swath of social and economic life (van Dijck, 2020)-remains outside its field of vision.

I theorize these blind spots as partly attributable to the dominance and insularity of the competition policy framework as a foundation for governing platform sectors. Indeed, these antitrust debates were siloed from complementary policy debates about issues like privacy, political influence, and content moderation. Even efforts to overcome policy silos, like the Stigler Report, largely deferred to the corrective power of market mechanisms. This persistent deference illuminates the neoliberal constraints on the policy debate and, more broadly, on policy efforts to imagine and define a robust governance regime over rapidly transforming digital platform markets.

\section{References}

Andrews, L. (2020, July 8). Facebook 'Regulation': a process not a text. CREATe - UK Copyright and Creative Economy Centre, University of Glasgow. http://doi.org/10.5281/zenodo.3933014

Evens, T., Donders, K., \& Afilipoaie, A. (2020). Platform policies in the European Union: Competition and public interest in media markets. Journal of Digital Media \& Policy, 11(3), 283-300. https://doi.org/10.1386/jdmp 000261

Fischer, F. (2003). Reframing public policy: Discursive politics and deliberative practices. Oxford University Press.

Haggart, B. (2020). Global platform governance and the internet-governance impossibility theorem. Journal of Digital Media \& Policy, 11(3), 321-339. https://doi.org/10.1386/jdmp 000281

Hassan, Y., Ganapati, S., \& Reddick, C. G. (2020). The politics of sharing: Sociotechnical imaginaries of digital platforms. Information Polity, 25(2), 159-176. https://doi.org/10.3233/ip-190203 
Puppis, M., \& Winseck, D. (2020, July 29). Platform Regulation Inquiries, Reviews and Proceedings Worldwide.

https://docs.google.com/document/d/1AZdh9sECGFTQROQjo5fYeiY gezdf 11 B8mQFsuMfs/edit?usp=sharing

Schmidt, V. A. (2015). Discursive institutionalism: understanding policy in context. In F. Fischer, D. Torgerson, A. Durnová, \& M. Orsini (Eds.), Handbook of critical policy studies (pp. 171-189). Edward Elgar Publishing.

Srnicek, N. (2017). Platform Capitalism. Polity.

van Dijck, J. (2020). Seeing the forest for the trees: Visualizing platformization and its governance. New Media \& Society, 1-19.

https://doi.org/10.1177/1461444820940293

Zuboff, S. (2019). The Age of Surveillance Capitalism: The fight for a human future at the frontier of power. Public Affairs. 